\title{
A review of important concepts in the trophic organization of pelagic ecosystems
}

\author{
M. R. LANDRY \\ Institute of Marine Resources, University of California, San Diego; \\ La Jolla, California, USA
}

\begin{abstract}
The physical environment has an important influence on the size composition of primary producers in plankton communities. This effect is transmitted through the trophic structure by size selective feeding processes at each level. A pictorial representation of trophic organization in pelagic ecosystems is presented which illustrates the complex involvement of individual species in the food web and the dynamic nature of ecosystem development along alternate pathways.
\end{abstract}

\section{INTRODUCTION}

The trophic organization of pelagic ecosystems has long been recognized as an important consideration in assessing the ultimate yield of the oceans in terms of fisheries (Steele, 1965; Ryther, 1969; Parsons \& LeBrasseur, 1970). Trophic structures of plankton communities in areas of high and low fish yields have been characterized as fundamentally different, based on the position of fish relative to the source of primary production in a linearized food chain. Recent efforts towards understanding the predictable consequences of pollutant additions and fisheries overexploitation within planktonic communities have de-emphasized the abstraction of an inflexible food chain in favor of a multidirectional web approach which more realistically represents the roles of different taxa and size classes in alternate pathways of ecosystem development (Greve \& $x$ Parsons, in press; Steele \& Frost, in prep.). My aim in this paper is to review important concepts in the trophic organization of planktonic communities within a context which is relevant to a dynamic interpretation of the environmental control of trophic-structure development in pelagic ecosystems and the potential effects of man's impact on the marine environment.

* This research was supported in full by the National Science Foundation, Grant No. NSF OCE76-02035. 


\section{GENERALIZED PROCESSES}

There is considerable evidence from field observations and laboratory studies that the nature of the physical environment significantly affects dominance among different size groups of phytoplankton. The relative importance of large species, particularly chain-forming diatoms, increases in environments where nutrients are available in high concentrations, e.g., along transects from oceanic to coastal areas (Malone, 1971a) or from subtropical to temperate and polar areas (Yentsch \& Ryther, 1959; Hulburt, 1964). Similarly, diatoms decrease in importance as nutrients are depleted in the later stages of temperate blooms (Malone, 1971b). These observations are supported by laboratory experiments indicating that at high nutrient concentrations common coastal forms of chain-forming diatoms do, in fact, grow at significantly faster rates than representative species of smaller oceanic forms (Eppley et al., 1969; Parsons \& Takahashi, 1973).

Margalef (1974) has incorporated these observations into a general model of phytoplankton community organization which emphasizes the dual importance of nutrient concentrations and turbulent mixing. The model proposed by Margalef is quite similar to earlier suggestions that the size composition of phytoplankton is affected by the nature of the physical environment (Semina, 1968; Semina, 1969). These authors have related the dominance of large diatoms to areas of net upward movement of water through the pycnocline; a correlation between vertical water transport and the rate of nutrient addition is implied.

Areas of high nutrients and turbulence promote the dominance of fast growing diatoms. Decreasing turbulence decreases the net growth rate of diatoms, even when nutrients are relatively high, by increasing losses due to sinking (Smayda, 1970). Decreasing nutrient concentrations have the effects of decreasing growth rate directly and also increasing the rate of sinking since buoyancy is influenced by the physiological state of diatoms (Gross \& Zeuthen, 1948; Steele \& Yentsch, 1960). The net effect of increased stability and decreased nutrients shifts the growth advantage from large diatoms to dinoflagellates and microflagellates which are able to maintain their vertical position in the water column and utilize nutrients efficiently at low concentrations.

In addition to phytoplankton, heterotrophic bacteria and detritus are also potentially utilized by zooplankton in the seas. The importance of bacterial production in oligotrophic tropical seas is a matter on which there is little concensus (Sorokin, 1971a; Banse, 1974; Sieburth et al., in press). In temperate and polar seas and in areas over the continental shelf, however, bacteria are generally belicved to be less important relative to phytoplankton (Sorokin, 1971b; Ferguson \& Rublee, 1976; Sieburth, pers. comm.). One possible reason is that the fraction of primary production which is released as dissolved organic matter and, therefore, available to bacteria is relatively low in coastal areas but increases dramatically with increasing oligotrophy (Thomas, 1971). A large portion of particulate organic matter in the oceans is often in the form of detritus, but little is known of its size distribution, and its nutritional value is questionable (Paffenhöfer \& Strickland, 1970).

The conclusions that can be reached regarding the size availability of food for primary consumers in different physical environments are basically similar if phyto- 
plankton is considered alone or in conjunction with bacteria and detritus. Nutrient rich areas where large diatoms are expected to be favored are areas where bacteria are generally insignificant and where almost all of the particulate organic matter is alive (Finenko \& Zaika, 1970). The increasing importance of bacteria in stable, oligotrophic regions complements the observed trend toward decreasing size of phytoplankton.

Filter feeding copepods are usually the dominant herbivores in plankton communities. While their mechanism of feeding seems relatively non-selective, copepods do differ appreciably in their abilities to capture and utilize particles of different sizes. The size spectrum of particles which can be utilized by a copepod can be roughly defined by the spacing of fine hairs on its filtering appendages which determines the minimum size which can be retained (Nival $\&$ Nival, 1976) and the size of the animal and its feeding appendages which determine the upper size of particles that can be handled effectively (Burns, 1968). Within this range, copepods exploit larger sizes of cells more efficiently than smaller cells. That is, at a given biomass of particles, copepods generally ingest more and grow faster if the particles are larger, even though they are less abundant than smaller particles (Mullin, 1963; Richman \& Rogers, 1969; Frost, 1972). Consequently, small particles, which are proportionately larger to small grazers than to larger grazers, are exploited more efficiently by the smaller grazers (Frost, 1974). This advantage of small cells may in part be due to a reduction in the spacing of setae on the feeding appendages of smaller copepods (Nival \& Nival, 1976). Large copepods, and large crustaceans, in general, require larger food particles for optimal growth than smaller species (Parsons et al., 1967).

Microzooplankton, ciliates and small nauplii, are the smallest size class of consumer in the plankton and are, consequently, restricted to exploiting only the smallest sizes of food particles. It is, therefore, not surprising that they are proportionately more important, relative to the total zooplankton biomass, in stable oceanic environments where small flagellates and bacteria are the favored primary producers (Beers \& Stewart, 1967, 1969). It has been suggested that they function as trophic level intermediates in these environments, converting the energy available in small particles into larger particles which are more effectively used by small and medium sized omnivores (Beers \& Stewart, 1969).

As we consider the feeding processes of carnivores, it is still useful to emphasize the partitioning of resources on the basis of food size. The concept of species, however, assumes a greater importance than in the relationship between filter-feeding zooplankton and the size range of available food. Prey species of a given size differ in their swimming and escape behavior, and predators differ in their tactics of predation. Active prey with fast escape responses are less accessible to active predators than are sluggish prey, everything else being equal. On the other hand, active prey may have a greater tendency to blunder into traps set by ambush predators such as ctenophores and jellyfish.

One possible way to partition the size classes of zooplankton as food is on the basis of vertebrate and invertebrate predators. This division seems intuitively proper but the evidence is indirect.

As suggested by observation in freshwater ecosystems, pelagic fish apparently 
exert a disproportionate mortality effect on larger species of zooplankton (Brooks \& Dodson, 1965; Warshaw, 1972). Larger zooplankton which usually dominate plankton assemblages in these areas become relatively rare following the introduction of fish. To some extent, the dramatic change in species composition which follows the entry of planktivorous fish in a small lake may be partly due to the fact that the invertebrate predators, which exploit smaller stages and species of zooplankton, will be among the larger prey which are selected by the fish. Thus, fish exert a double effect on the system by increasing the rate of mortality of larger species while increasing the survival potential of smaller zooplankton.

The energetic benefits of preferential feeding on large prey by fish have been demonstrated theoretically by Kerr (1971) and are supported by laboratory and field evidence. Parsons \& LeBrasseur (1970), for example, have shown that juvenile pink salmon $(90 \mathrm{~mm})$ were able to satisfy their metabolic requirements when feeding on the relatively large copepod Calanus plumchrus, but that they would undoubtedly starve if they were fed solely on a smaller species Pseudocalanus minutus, even at much higher concentrations in terms of prey biomass. The benefits of larger prey size have been observed by Kerr \& Martin (1970) to counteract the introduction of an intermediate carnivore in a lake ecosystem without affecting the yield of the top carnivore. Changes in the size composition of the plankton from a Pseudocalanus dominated system to one dominated by Calanus have also markedly affected growth and recruitment in the North Sea herring fishery (Cushing, 1975).

Clearly, not all fish selectively feed on the largest of all available prey. Size preference must change as fish grow; certainly, in the initial stages of life small copepodids, nauplii and algae may be the only food source which the larvae can effectively handle (Parsons \& LeBrasseur, 1970; Cushing, 1975). In subsequent life, feeding behavior will also depend on the relative abundances of preferred large prey and suboptimal, but adequate, smaller prey (LeBrasseur et al., 1969; O'Connell, 1972; Isaacs \& Wick, 1973).

Invertebrates appear to follow the same principle of growth optimization as fish, i.e. they tend to preferentially select larger prey as they grow (Reeve \& Walter, 1972). Not discounting the fact that fish are active, visual feeders and, perhaps better able to act on their perceptions of prey size than most invertebrate predators, the chief difference between the two types of predators is probảbly one of size. Because invertebrate predators are usually the smallest predators in the plankton, the smaller size classes of prey, nauplii and small copepodids, represent large morsels of food relative to their size and are, therefore, likely to be more energetically attractive to invertebrates than they are to fish. Among planktonic copepods in coastal areas, the highest rates of mortality occur in the naupliar stages; generally, $10 \%$ or less can be expected to survive to the larger copepodid stages (Heinle, 1966; Parsons et al., 1969; Mullin \& Brooks, 1970). Perhaps this is a good indication of the effect of small invertebrates relative to the effect of fish and large invertebrates on the population dynamics of marine zooplankton in general. 


\section{TROPHIC ORGANIZATION}

The preceding discussion of trophic processes in pelagic ecosystems can be summarized in a simple diagram of trophic organization (Fig. 1). Dominant pathways along which matter and energy are channeled in the system are represented by qualitative differences in the widths of arrows. Organisms pictured in the figure were

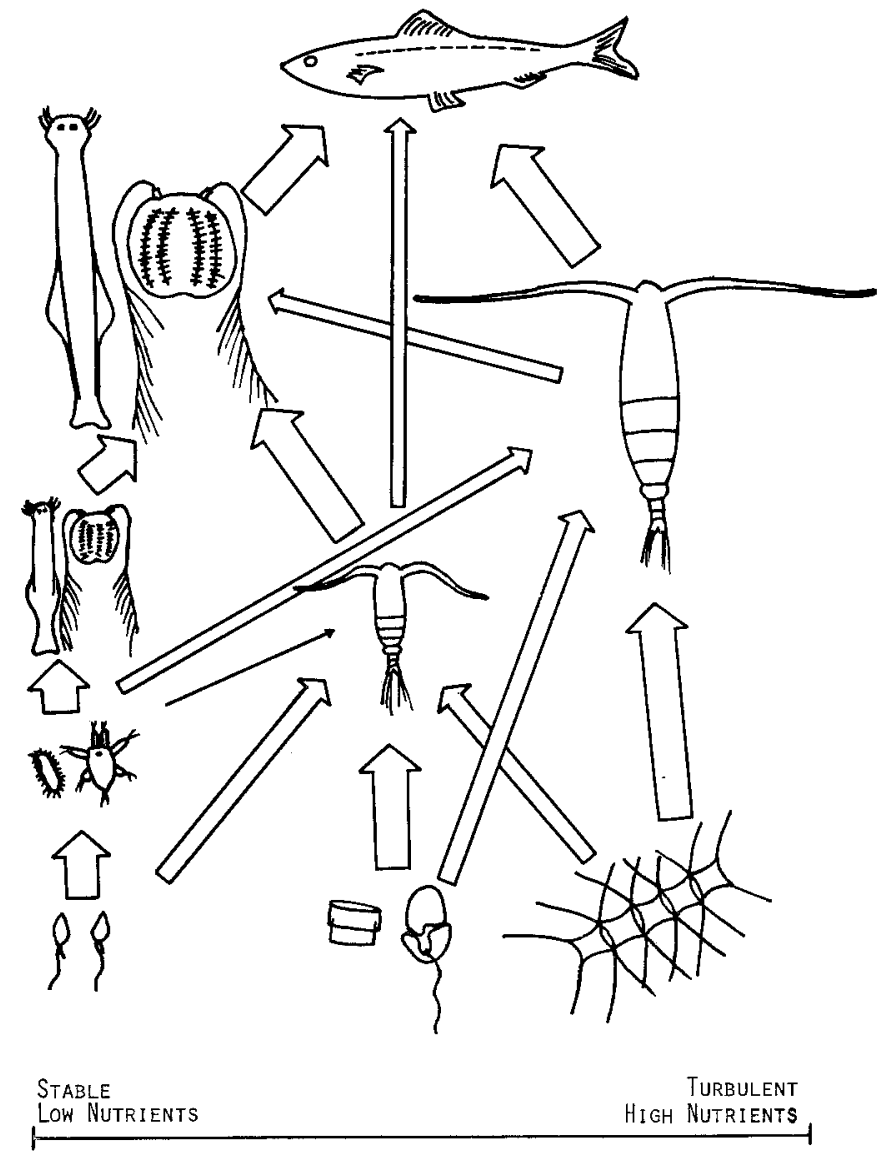

Fig. 1: Trophic organization in pelagic ecosystems

chosen to characterize easily recognizable types, e.g. chaetognaths and ctenophores represent invertebrate predators but may, in fact, be less important in some situations than predatory crustaceans which were not included. Ctenophores may also not be directly eaten by herring-like fish, but the basic idea that most invertebrate predators will eventually be consumed by fish of some sort seems reasonably accurate.

The physical environment exerts a strong influence on the trophic pathways which are emphasized in pelagic ecosystems. High nutrient, high turbulent (upward transport) environments favor the growth of large chain-forming diatoms which are con- 
sumed with greater efficiency by larger herbivores than by smaller species. The growth of fish and large invertebrate predators is, therefore, enhanced by the availability of larger prey. Thus, the dominant pathway is short and the yield, in terms of a commercially exploitable fishery, is relatively large. Within this scheme, the relative richness of the environment is an important variable in determining the length of the pathway. In upwelling areas, for example, the concentrations of diatoms may be dense enough for larger consumers to exploit them directly, thus, bypassing intermediate herbivores. Behavioral adaptations which allow for the exploitation of dense patches of small prey as if they were one large prey, e.g., the blue whale feeding on krill, also lead to the shortening of trophic pathways.

Areas of low nutrients and low turbulence (downward transport) are the other extreme in the environmental spectrum. The primary producers in these regions are dominated by microflagellate species and, perhaps, bacteria which are only efficiently exploited by small herbivores and micro-zooplankton. These, in turn, are consumed by small invertebrate omnivores or carnivores of which there might be several intermediate levels before they are large enough to be utilized by exploitable fish stocks. Thus, as Ryther (1969) has suggested, even though tropical oceans have an annual primary production of about one-half of productive, temperate areas, their potential yield of fish is orders of magnitude less because trophic structure is organized in longer pathways, each intermediate level resulting in an appreciable loss in the transfer of energy. This view is consistent with observations that the relative importance of predatory zooplankton increases in stable tropical oceans (Grice \& Hart, 1962; Timonin, 1969).

Representatives of all size classes of producers and consumers are present in every plankton community; the difference between environments is the emphasis which is placed on the dominant pathways on energy transfer. Micro-zooplankton, for example, are more abundant in terms of numbers and biomass in coastal areas than in stable oceanic areas (Beers \& Stewart, 1967, 1969). Their importance relative to the total zooplankton community is not as great, however, but it is not necessarily negligible.

One of the difficulties in abstracting pelagic ecosystems into simple food chains is that the importance of alternate pathways is not fully appreciated. In considering a food chain involving large diatoms, Calanus, and herring, for example, it is easy to stereotype Calanus as a large herbivore and to forget that if the adults of the species are present, the other developmental stages must also be present at some time. Thus clarified, it is necessary to consider the availability of food which can be utilized by the smaller stages and the predators which exploit them. Growing animals occupy a variety of trophic niches, each definable in terms of how the animals perceive the available resource range and how they are perceived by predators. Petipa (1967) interpreted the various developmental changes which occur in growing copepods as different life-forms. She suggested that it was impossible to understand species dynamics in the plankton by comparing species solely on the basis of their mature forms. One has to understand how different life forms of a given species affect and are affected by the ecosystem, and how the advantages which species enjoy over one another change as they develop. 
The involvement of individual species in competing trophic pathways causes the interspecies relationships in pelagic ecosystems to be highly complex. Isaacs (1972, 1973) refers to this as an unstructured food web to emphasize the fact that there are no clear food chains in plankton assemblages in which species occupy defined trophic levels. Within the food web complex, the transmission of energy and matter tends to be redirected many times between species. A practical consequence of this is that toxic pollutants become highly and uniformly concentrated in the zooplankton. An ecological consequence is that the roles of predators and prey may be frequently exchanged in the plankton, the adults of prey species feeding on young predators. In some instances, this may allow prey to exert a direct control on their predators (Greve, in press).

The model of trophic organization presented in this paper is structured from bottom to top, i.e. at each level the direction of energy transfer is determined solely on the basis of the most efficient utilization by consumers of the available resources. Thus, an opportunistic interpretation of predator-prey relationships is emphasized.

Margalef (1975) has suggested that natural processes drive ecosystems to oligotrophy and that eutrophic systems only exist where large inputs of external energy periodically occur. The trophic pathway which is based on large diatoms is clearly dependent on the input of external energy as turbulence (upwelling) and nutrients. The pathway is not internally stable in the absence of this input as is indicated by the succession of phytoplankton species from large to small forms when stability in the water column increases and nutrient depletion occurs. One possible way to interpret this pathway is that it exists in an unbalanced state. Local upwelling are exploited by diatoms and these, in turn, by large herbivores after an initial lag time and until the natural succession to small flagellates occurs. At any given time, the physical environment might consist of various local environments in different successional states.

Steele \& Frost (in prep.) have suggested from the results of a multispecies simulation model that the overexploitation of planktivorous fish in pelagic ecosystem could have a significant effect on the size and species composition of the phytoplankton and zooplankton. The immediate consequence of fish removal would be a reduction in predation pressure on large herbivores and invertebrate predators; increases in the grazing pressure on large phytoplankton and predation pressure on small herbivores, thereby reducing the utilization of small phytoplankton, would follow. Thus, the ultimate result would be on ecosystem dominated by microflagellates which large herbivores would not be able to exploit.

The opportunistic model of trophic organization presented here offers an alternate view of the effects of fish removal from pelagic ecosystems. The trophic pathway represented by large diatoms and large herbivores is in a state of disequilibrium and depends on periodic reinitiation by physical processes. It may, therefore, remain relatively unaffected by the removal of fish or, at least, will not be affected as dramatically as Steele \& Frost (in prep.) have suggested it might be. If this interpretation is valid, it would be improper to assume that trophic relations in the plankton and the effects of environmental perturbations and heterogeneity can be studied as isolated processes with the ultimate result being a predictive understanding of pelagic eco- 
systems. Future advances in this field will have to emphasize the relationships between biological and physical processes in the oceans and how these affect the development of trophic organization along alternate pathways.

Acknowledgements. I gratefully acknowledge the contributions and suggestions of Drs. M. Mullin, K. Banse, J. Sieburth, and W. Greve.

\section{LITERATURE CITED}

Banse, K., 1974. On the role of bacterioplankton in the tropical ocean. Mar. Biol. 24, 1-6.

Beers, J. R. \& Stewart, G. L., 1967. Micro-zooplankton in the euphotic zone at five locations across the California Current. J. Fish. Res. Bd Can. 24, 2053-2068.

- - 1969. The vertical distribution of micro-zooplankton and some ecological observations. J. Cons. perm. int. Explor. Mer 33, 30-44.

Brooks, J. L. \& Dodson, S. I., 1965. Predation, body size, and composition of plankton. Science, N. Y. 150, 28-35.

Burns, C. W., 1968. The relationship between body size of filter-feeding cladocera and the maximum size of particle ingested. Limnol. Oceanogr. 13, 675-678.

Cushing, D. H., 1975. Marine ecology and fisheries. Cambridge Univ. Press, Cambridge, 278 pp.

Eppley, R. W., Rogers, J. N. \& McCarthy, J. J., 1969. Half-saturation constants for uptake of nitrate and ammonium by marine phytoplankton. Limnol. Oceanogr. 6, 912-920.

Ferguson, R. L. \& Rublee, P., 1976. Contribution of bacteria to standing crop of coastal plankton. Limnol. Oceanogr. 21, 141-145.

Finenko, Z. Z. \& Zaika, V. E., 1970. Particulate organic matter and its role in the productivity of the sea. In: Marine food chains. Ed. by J. H. Steele. Oliver \& Boyd, Edinburgh, 32-45.

Frost, B. W., 1972. Effects of size and concentration of food particles on the feeding behavior of the marine planktonic copepod Calanus pacificus. Limnol. Oceanogr. 17, 805-815.

- 1974. Feeding processes at lower trophic levels in pelagic communities. In: The biology of the oceanic Pacific. Ed. by C. B. Miller. Oregon State Univ. Press, Corvallis, 59-77.

Greve, W. Interspecific interaction: the analysis of complex structures in carnivorous zooplankton populations. Helgoländer wiss. Meeresunters. (In press)

- \& Parsons, T. R. Photosynthesis and fish production: the possible effects of climatic change and pollution. Helgoländer wiss. Meeresunters. (In press)

Grice, G. D. \& Hart, A. D., 1962. The abundance, seasonal occurrence and distribution of the epizooplankton between New York and Bermuda. Ecol. Monogr. 32, 287-309.

Gross, F. \& Zeuthen, E., 1948. The buoyancy of plankton diatoms: a problem of cell physiology. Proc. R. Soc. (B) 135, 382-389.

Heinle, D. R., 1966. Production of a calanoid copepod, Acartia tonsa, in the Patuxent River estuary. Chesapeake Sci. 7, 59-74.

Hulburt, E. M., 1964. Succession and diversity in the plankton flora of the western North Atlantic. Bull. mar. Sci. Gulf Caribb. 14, 33-44.

Isaacs, J. D., 1972. Unstructured marine food webs and "pollutant analogues". Fish. Bull. U.S. 70, $1053-1059$.

- 1973. Potential trophic biomasses and trace-substance concentrations in unstructured marine food webs. Mar. Biol. 22, 97-104.

- \& Wick, G. L., 1973. Optimized tactics for open-water marine predators. Spec. Publ. mar. biol. Ass. India, 193-199.

Kerr, S. R., 1971. A simulation model of lake trout growth. J. Fish. Res. Bd Can. 28, 815-819.

- \& Martin, N. V., 1970. Trophic-dynamics of lake trout production systems. In: Marine food chains. Ed. by J. H. Steele. Oliver \& Boyd, Edinburgh, 365-376.

LeBrasseur, R. J., Barraclough, W. E., Kennedy, O. D. \& Parsons, T. R., 1969. Production studies in the Strait of Georgia. Part III. Observations on the food of larval and juvenile fish in the Fraser River plume, February to May, 1967. J. exp. mar. Biol. Ecol. 3, 51-61. 
Malone, T. C., 1971a. The relative importance of nannoplankton and netplankton as primary producers in tropical oceanic and neritic phytoplankton communities. Limnol. Oceanogr. 16, 633-639.

- 1971b. The relative importance of nannoplankton and netplankton as primary producers in the California Current system. Fish. Bull. U.S. 69, 799-820.

Margalef, R., 1974. Ecologia. Ediciones Omega, Barcelona, 951 pp.

- 1975. External factors and ecosystem stability. Schweiz. Z. Hydrol. 37, 102-117.

Mullin, M. M., 1963. Some factors affecting the feeding of marine copepods of the genus $\mathrm{Ca}$ lanus. Limnol. Oceanogr. 8, 239-250.

- \& Brooks, E. R., 1970. Production of the planktonic copepod, Calanus belgolandicus Bull. Scripps Instn Oceanogr. tech. Ser. 17, 89-103.

Nival, P. \& Nival, S., 1976. Particle retention efficiencies of an herbivorous copepod, Acartia clausi (adult and copepodite stages): Effects on grazing. Limnol. Oceanogr. 21, 24-28.

O'Connell, C. P., 1972. The interrelation of biting and filtering in the feeding activity of the northern anchovy (Engraulis mordax). J. Fish. Res. Bd Can. 29, 285-293.

Paffenhöfer, G. A. \& Strickland, J. D. H., 1970. A note on the feeding of Calanus helgolandicus on detritus. Mar. Biol. 5, 97-99.

Parsons, T. R. \& LeBrasseur, R. J., 1970. The availability of food to different trophic levels in the marine food chain. In: Marine food chains. Ed. by J. H. Steele. Oliver \& Boyd, Endinburgh, 325-343.

- - \& Fulton, J. D., 1967. Some observations on the dependence of zooplankton grazing on the cell size and composition of phytoplankton blooms. J. oceanogr. Soc. Japan 23, 10-17.

- - \& Kennedy, O. D., 1969. Production studies in the Strait of Georgia. II. Secondary production under the Fraser River Plume, February to May, 1967. J. exp. mar. Biol. Ecol. $3,39-50$.

- \& Takahashi, M., 1973. Environmental control of phytoplankton cell size. Limnol. Oceanogr. 18, 511-515.

Petipa, T. S., 1967. On the life-forms of pelagic copepods and the question of the structure of trophic levels. In: Structure and dynamics of aquatic communities and populations. Akad. Nauk. SSSR Inst. Biol. Southern Seas, 108-119.

Reeve, M. R. \& Walter, M. A., 1972. Conditions of culture, food-size selection, and the effects of temperature and salinity on growth rate and generation time in Sagitta bispida Conant. J. exp. mar. Biol. Ecol. 9, 191-200.

Richman, S. \& Rogers, J. N., 1969. The feeding of Calanus belgolandicus on syndhronously growing populations of the marine diatom Ditylum brightwellii. Limnol. Oceanogr. 14, 701-709.

Ryther, J. H., 1969. Photosynthesis and fish production in the sea. The production of organic matter and its conversion to higher forms of life vary throughout the world ocean. Science, N.Y. 166, 72-76.

Semina, G. I., 1969. The size of phytoplankton cells along longitude $174^{\circ} \mathrm{W}$ in the Pacific Ocean. Oceanology 9, 391-398.

Semina, H. J., 1968. Water movement and the size of phytoplankton cells. Sarsia 34, 267-272.

Sieburth, J. McN., Johnson, K. M., Lavoie, D. M. \& Burney, C. M. Diurnal periodicity of dissolved organic carbon release and uptake in the euphotic zone of the open North Atlantic. Helgoländer wiss. Meeresunters. (In press)

Smayda, T. J., 1970. The suspension and sinking of phytoplankton in the sea. Oceanogr. mar. Biol. 8, 353-414.

Sorokin, Yu. I., 1971a. On the role of bacteria in the productivity of tropical oceanic waters. Int. Rev. ges. Hydrobiol. 56, 1-48.

- 1971b. Bacterial populations as components of oceanic ecosystems. Mar. Biol. 11, 101-105.

Steele, J. H., 1965. Some problems in the study of marine resources. Spec. Publs. int. Commn. NW. Atlant. Fish. 6, 463-476.

- \& Frost, B. W. The structure of plankton communities. (In prep.)

- \& Yentsch, C. S., 1960. The vertical distribution of chlorophyll. J. mar. biol. Ass. U.K. 39, 217-226. 
Thomas, J. P., 1971. Release of dissolved organic matter from natural populations of marine phytoplankton. Mar. Biol. 11, 311-323.

Timonin, A. G., 1969. The structure of pelagic associations. The quantitative relationship between different trophic groups of plankton in the frontal zones of the tropical oceans. Oceanology 9, 686-694.

Warshaw, S. J., 1972. Effects of alewives (Alsoa pseudobarengus) on the zooplankton of Lake Wononskopomuc, Connecticut. Limnol. Oceanogr. 17, 816-825.

Yentsch, C. S. \& Ryther, J. H., 1959. Relative significance of the net phytoplankton and nannoplankton in the waters of Vineyard Sound. J. Cons. perm. int. Explor. Mer 24, 231-238.

Author's address: Dr. M. R. Landry

Institute of Marine Resources

University of California, San Diego

La Jolla, California 92093

USA 